\title{
THE EFFECT OF GOOD CORPORATE GOVERNANCE MECHANISM, CORPORATE SOCIAL RESPONSIBILITY, AND OPPORTUNITY SET INVESTMENTS ON CORPORATE VALUE (Empirical Study on Property and Real Estate Companies listed on the Indonesia Stock Exchange in 2014-2017)
}

\author{
Sely Megawati Wahyudi ${ }^{1}$ \\ Universitas Mercu Buana \\ Indonesia \\ Molina $^{3}$ \\ Universitas Nasioal \\ Indonesia
}

\author{
Wieta Chairunesia $^{2}$ \\ Universitas Mercu Buana \\ Indonesia \\ Erwin Indriyanto 4 \\ Universitas Nasioal \\ Indonesia
}

Article D0I: https://doi.org/10.36713/epra3921

\begin{abstract}
This study aims to analyze the effect of disclosure of Good Corporate Governance, Corporate Social Responsibility and Investment Oppurnity Set on Company Value. The sampling technique used was purposive sampling. The study was conducted on property and real estate companies with a research period of 2014-2017. The estimation of the research model used is multiple regression analysis.

The purpose of this study is to determine whether the disclosure of Good Corporate Governance, Corporate Social Responsibility, and Investment Opportunity Set and affect the Company's Value. This research involves 5 (five) variables consisting of 1 (one) dependent variable, 4 (four) independent variables, and the dependent variable in this study is Company Value. The independent variables in this study are Good Corporate Governance, Corporate Social Responsibility, and Investment Oppurtunity Set on Company Value.

The results of this study indicate that Good Corporate Governance, Corporate Social Responsibility has a significant effect on Company Value while the Investment Oppurtunity Set has no significant effect on company's value.

KEYWORDS: Corporate Social Responsibility, Good Corporate Governance, Institutional Ownership, Managerial Ownership, Investment Oppurtunity Set, Company Value.
\end{abstract}

\section{PRELIMINARY}

\section{Research Background}

The higher the stock price the higher the value of the company. The wealth of shareholders and companies is represented by the market price of shares which is a reflection of investment decisions, financing (financing), and asset management. There are various factors that affect a company's value, one of which is non-financial. Good corporate governance is one of the non-financial factors that can affect the value of the company. Good Corporate Governance
(GCG) is not a new phenomenon or regulation for companies, GCG has been developing for a long time and has become more prominent since the 1997 economic crisis experienced by Indonesia. The collapse of various companies at the time, one of which was suspected by bad corporate governance (bad governance).

The growth of property and real estate companies in Indonesia from 2015 to 2018 can also be seen based on the Indonesia Residental Property Price Index graph below: 


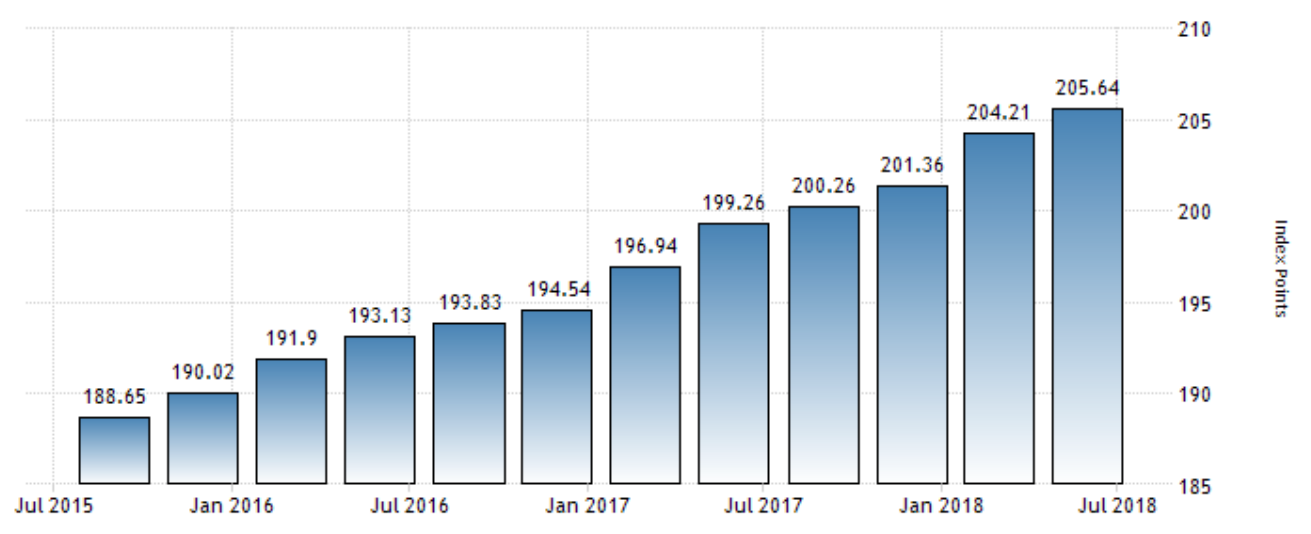

Gambar 1.1

Source: http://id.tradingeconomics.com/

The Housing Index in Indonesia increased to 205.64 index points in the second quarter of 2018 from 204.21 index points in the first quarter of 2018. The Housing Index in Indonesia averaged 196.65 index points from 2015 to 2018 , reaching an all-time high of 205,64 index points in the second quarter of 2018 and a record low of 188.65 index points in the fourth quarter of 2015.

Based on the above phenomenon it can be concluded that there are investment opportunities in the property and real estate fields that can attract investors. Investor's perception of the company's success rate is reflected through the value of the company which is closely related to its stock price. High stock prices make the value of the company also high and increase market confidence not only in the company's current performance but also in the company's future prospects (Salvatore, 2005) cited by (Uzliawati, et al. 2016).

If the company is able to create the right investment decisions, the company's assets will produce optimal performance so as to provide a positive signal for investors who will increase share prices and increase the value of the company. In general, Investment Opportunity Set (IOS) illustrates the breadth of investment opportunities or opportunities for a company, but highly dependent on the company's spending choices for the benefit of the future (Astriani, 2014).

Investment Opportunity Set (IOS) is a choice of future investment opportunities that can affect the growth of company or project assets that have a positive net present value. According to Hidayah (2015), IOS is a company value that depends on expenses determined by management in the future, which at present are investment choices that are expected to produce greater returns. Research by Sudiani and Darmayanti (2016) which analyzes the effect of profitability, liquidity, growth and investment opportunity set on firm value, the results of the research prove that IOS has a significant positive effect on firm value.

In a study conducted by Diana Istighfarin and Ni Gusti Putu Wirawati (2015), GCG with 4 proxies namely institutional ownership, the size of the independent board of commissioners, the audit committee and the Good Governance Perception Index (GGPI) obtained research results namely institutional ownership and GGPI have significant positive effect on profitability, while the size of the board of commissioners and audit committee has no significant effect on profitability.

Previous studies on the influence of corporate social responsibility and profitability on firm value were conducted by Zarlia and Salim (2014). The results of this study indicate that CSR influences company value. Rahardjo and Murdani (2016) found that CSR has a significant effect on firm value, while the research of Putri, et al. (2016) shows that corporate value is not influenced by corporate social responsibility.

Much research has been done on the effect of investment opportunity sets on firm value. Research Syardiana, et al. (2015) found that investment opportunity set had a significant positive effect on firm value. This is the same as the results of research conducted by Hidayah (2015) which shows that the investment opportunity set (IOS) has a positive and significant impact on the value of the Company.

As a result of the emergence of the research gap or research gap makes researchers interested in re-examining these variables. In this study the samples taken were property and real estate companies that went public on the Indonesia Stock Exchange with a set period of time from 2014 - 2017.

based on the background of the problems above, the authors intend to conduct research and then the results will be outlined in the form of a thesis entitled 


\section{Formulation of the problem}

Based on the background that has been described, the formulation of the problem in this study are:

1. Is there any influence of GCG disclosure on company value?

2. Is there an influence of CSR disclosure on company value?

3. Is there an influence of IOS disclosure on company value?

\section{Research purposes}

The purpose of this study is to determine whether good corporate governance, corporate social responsibility, and investment opportunity set have an influence on firm value.

\section{LITERATURE REVIEW, FRAMEWORK FOR THINKING AND HYPOTHESES \\ Good Corporate Governance, Corporate Social Responsibility, and the Cost of Equity}

\section{Good Corporate Governance}

According to the Forum for Corporate Governance in Indonesia (FCGI), (2001: 2) corporate governance is defined as:

"A set of regulations governing the relationship between holders, managers (managers) of the company, creditors, government, employees, and other internal and external stakeholders relating to their rights and obligations or in other words a system that controls the company. The purpose of corporate governance is to create added value for all interested parties (stakeholders).

While the definition that is not much different was put forward by the Organization for Economic Cooperation and Development (OECD), namely corporate governance is a system where business companies are directed and controlled. The corporate governance structure determines the distribution of rights and responsibilities between different participants in the company, such as boards, managers, shareholders and other stakeholders, and details the rules and procedures for decision making on company affairs. By doing this, it also provides a structure through which the company's goals are set, and how to achieve those goals and monitor performance. In this study, corporate governance in accordance with its internal mechanisms uses managerial ownership and institutional ownership.

\section{Corporate Social Responsibility}

Putri, et al. (2016) defines corporate social responsibility as the company's efforts to balance its commitments to groups and individuals in the corporate environment, including customers, other companies, employees, and investors. CSR is an idea that makes a company not only responsible in financial terms, but also towards social and environmental problems around the company so that the company can grow sustainably (Rosiana, et al. 2013).

Understanding CSR according to Johnson and Johnson, in the book Nor Hadi (2011: 46) quoted by Rahardjo and Murdani (2016) states that:

"CSR is about how companies manage the business processes to produce an overall positive impact to society". This definition basically departs from the philosophy of how to manage a company either in part or in whole has a positive impact on itself and its environment. Corporate social responsibility or Corporate Social Responsibility (CSR) is a mechanism for an organization to voluntarily integrate environmental and social attention into its operations and interactions with stakeholders, which exceeds organizational responsibility in the field of law (Kusumadilaga, 2010).

The Corporate Social Responsibility currently disclosed in the Sustainability Report reports transparently the economic, environmental and social impacts of company activities. Openness about these matters will convince stakeholders that the company has been managed well and that the company has paid attention to the interests of investors and thus will build investor confidence (Anggraini, 2018 in Tanjung, 2019)

CSR Disclosure is the disclosure of information relating to the environment in the company's annual report. In measuring CSR Disclosure, the CSR index is used which is the relative area of disclosure of each sample company for the social disclosures it does, where the measurement instruments in the checklist that will be used in this study refer to the instrument used by Sembiring (2005), which groups CSR information into 7 categories namely: the environment, energy, health and safety of the workforce, other labor, products, community involvement, and the public. This category was adopted from the research of Hackston and Milne (1996). The seven categories are divided into 90 disclosure items. Based on Bapepam Regulation No. VIII.G.2 regarding annual reports, there are 12 items out of 90 disclosure items which are not suitable to be applied to the conditions in Indonesia. Further adjustments were made by removing the 12 disclosure items, so that a total of 78 disclosure items remained. 


\section{Investment Opportunity Set}

To achieve company goals, managers make investment decisions that produce positive net present value. Investment opportunity set is a combination of the assets owned by the company (assets in place) and the selection of investments in the future with a positive net present value (Syardianaet al., 2015). Both will determine funding decisions in the future. According to Hidayah (2015), IOS is a company value whose amount depends on expenses determined by management in the future, which at this time are still investment choices that are expected to produce greater returns.

In general, IOS can be said to describe the extent of investment opportunities or opportunities for a company, but it really depends on the company's expenditure for the benefit of the future. IOS gives a positive signal about the company's growth in the future, thus increasing stock prices as an indicator of company value, if the stock price rises, the company's value will be high (Astriani, 2014). Investment Opportunity Proxy Set can be classified into several proxies.

One of them is price-based proxy. This proxy is based on the difference between assets and the market value of the stock. So this proxy is strongly influenced by market prices, price-based proxy states that the company's growth is partially expressed by stock prices, then the company that has high growth will have a higher market value than the assets owned (Putri, 2013). IOS that produces figures close to $100 \%$ ratio means the company has a high investment opportunity to manage its company so as to produce a large return to increase the company's value.

\section{Company Value}

Company value is a certain condition that has been achieved by a company as an illustration of public trust in the company after going through a process of activities for several years, namely since the company was founded until now. According to Husnan (2013) the value of a company or also referred to as the company's market value is the price that prospective buyers are willing to pay if the company is sold.

According to Gitosudarmo and Basri (2000) the notion of corporate value is:

"The value of the company is the current value of the company and the value in the future time and money, therefore it is necessary to consider the value of time and money. Consideration of time and money is used to assess expenses or income that will be received in the future, while evaluations and decisions must be made now (present value). "

The value of the company is very important because with high company value will be followed by high shareholder prosperity. Wealth of shareholders and companies is represented by the market price of shares which is a reflection of investment decisions, funding and asset management.

\section{Previous Research}

In a study conducted by Diana Istighfarin and $\mathrm{Ni}$ Gusti Putu Wirawati (2015), GCG with 4 proxies namely institutional ownership, the size of the independent board of commissioners, the audit committee and the Good Governance Perception Index (CGPI) obtained research results namely institutional ownership and CGPI have significant positive effect on profitability, while the size of the board of commissioners and audit committee has no significant effect on profitability.

Previous studies on the influence of corporate social responsibility and profitability on firm value were conducted by Zarlia and Salim (2014). The results of this study indicate that CSR influences company value. Rahardjo and Murdani (2016) found that CSR has a significant effect on firm value, while the research of Putri, et al. (2016) shows that corporate value is not influenced by corporate social responsibility.

Much research has been done on the effect of investment opportunity sets on firm value. Research Syardiana, et al. (2015) found that investment opportunity set had a significant positive effect on firm value. This is the same as the results of research conducted by Hidayah (2015) which shows that the investment opportunity set (IOS) has a positive and significant impact on the value of the Company.

Research by Sudiani and Darmayanti (2016) which analyzes the effect of profitability, liquidity, growth and investment opportunity set on firm value, the results of the research prove that IOS has a significant positive effect on firm value. 


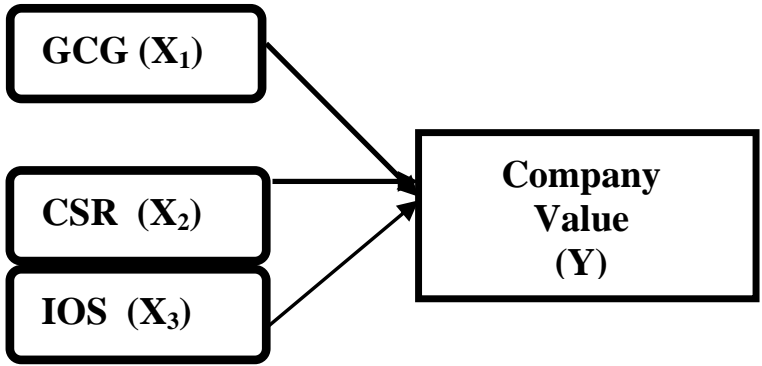

\section{RESEARCH METHODS}

\section{Population and Research Samples}

The population in this study are all property and real estate companies that have been listed on the Indonesia Stock Exchange. Data collection techniques with a purposive sampling method, the sampling is based on certain criteria. The criteria used in this study are:

1. The sample companies are property and real estate companies listed on the Indonesia Stock Exchange in the 2014-2017 period.

2. The sample companies publish financial statements for succession in the period 2014 2017.

3. The sample companies implement CSR in the 2014-2017 period

4. The sample companies have complete variables in the financial statements for 2014-2017.

\section{Data analysis method}

Data analysis was performed using multiple linear regression analysis including the following analysis:

\section{a. Partial Test ( $\mathrm{t}$ test)}

This test is conducted to determine whether the independent / partially independent variable has a significant influence on the dependent / dependent variable. Based on the significant basis of decision making are:

If the significance is $>0.05$ then $\mathrm{H}$ is rejected
If significance $<0.05, \mathrm{H}$ is accepted

b. Hypothesis testing

Hypothesis Test aims to predict the magnitude of the influence of the dependent variable (dependent variable) by using the independent variable (independent variable). The multiple regression equation is:

$$
\mathrm{Y}=\mathrm{a}+\mathrm{b} 1 \mathrm{x} 1+\mathrm{b} 2 \mathrm{x} 2+\mathrm{b} 3 \times 3+\mathrm{e}
$$

Description:

$\begin{array}{llll}\text { Y } & : & \text { Company Value } \\ \mathrm{a} & : & \text { Constant } & \\ \mathrm{x} 1 & : & \text { GCG } \\ \mathrm{x} 2 & : & \text { CSR } \\ \mathrm{x} 3 & : & \text { IOS } \\ \beta 1-\beta 3 & : & \text { Regression coefficient } & \text { for } \\ \text { variable } & & \\ \mathrm{e} & : & \text { error }\end{array}$

\section{RESEARCH RESULTS AND DISCUSSION \\ Hypothesis Testing and Discussion}

The statistical $t$ test basically shows how far partially the influence of an independent variable is in explaining the variation of the dependent variable (Ghozali, 2005). Here are the results of the SSSS from the $t$ test presented. 
Source: data processed with SPSS 23

From the table above, it can be seen that $\mathrm{t}$ count is 1,882 for KM, $-1,323$ for KI, 2,971 for CSR and 0.520 for IOS. Then also obtained t table 0.68067 (2-tailed test). And it can be concluded:

1. For the $\mathrm{KM}$ variable that is $\mathrm{T}$ Count $<\mathrm{T}$ Table (1.882> 0.68067) means that partially a significant influence between KM and NP. So from this case it can be concluded that KM partially has a significant effect on NP on Property and Real Estate Companies listed on the Indonesia Stock Exchange in 2014-2017.

2. For the variable KI namely $\mathrm{T}$ Calculate $<\mathrm{T}$ Table $(1,323>0.68067)$ means that partially a significant influence between KI and NP. So from this case it can be concluded that KI partially has a significant effect on NPs on Property and Real Estate Companies listed on the Indonesia Stock Exchange in 2014-2017.

3. For CSR variables, namely $\mathrm{T}$ Count $<\mathrm{T}$ Table (2.971> 0.68067) means that partially a significant influence between CSR and NP. So from this case it can be concluded that CSR partially has a significant effect on NPs on Property and Real Estate Companies listed on the Indonesia Stock Exchange in 2014-2017.

4. For IOS variables, namely $\mathrm{T}$ Count $<\mathrm{T}$ Table $(0.520>0.68067)$ means that partially a

\section{Coefficients ${ }^{\mathrm{a}}$}

\begin{tabular}{|c|c|c|}
\hline $\begin{array}{l}\text { Standardi } \\
\text { zed } \\
\text { Coefficien } \\
\text { ts } \\
\end{array}$ & & \\
\hline Beta & $t$ & Sig. \\
\hline & $\begin{array}{r}2,63 \\
5\end{array}$ & 012 \\
\hline -315 & $\begin{array}{r}1,88 \\
2\end{array}$ & 067, \\
\hline,- 204 & $\begin{array}{r}1,32 \\
3\end{array}$ & 194 \\
\hline 418, & $\begin{array}{r}2,97 \\
1\end{array}$ & 005, \\
\hline 076, & ,520 & 606 \\
\hline
\end{tabular}

significant influence between IOS and NP. So from this case it can be concluded that IOS partially has a significant effect on the NP on Property and Real Estate Companies listed on the Indonesia Stock Exchange in 2014-2017.

\section{Discussion}

\section{The effect of GCG on NP}

From the above analysis it can be concluded that $\mathrm{T}$ Calculate $>\mathrm{T}$ Table $(1.882>$ $0.68067)$ means that partially significant influence between KM with NP and T Calculate $<$ T Table $(1,323>0.68067)$ means partially significant influence between KI and NP. The results are the same as Dian Istighfaria and $\mathrm{Ni}$ Gusti Putu Wiranti's research (2015) by getting the results of institutional ownership affect profitability.

\section{The influence of CSR on NP}

From the above analysis it can be concluded that T Calculate $>\mathrm{T}$ Table (2.971> $0.68067)$ means that partially a significant influence between CSR and NP. The results are the same as Zarlia and Salim's (2014) research with the results that there is a significant influence on the disclosure of 
Corporate Social Responsibility on Company Value.

\section{Effect of IOS on COE}

From the above analysis it can be concluded that the $\mathrm{T}$ Count $<\mathrm{T}$ Table $(0.520>$ $0.68067)$ means that partially a significant influence between IOS and NP. These results are different from the research of Syardia, et all (2015) and Hidayah (2015) with the result that there is no significant effect of IOS disclosure on Company Value.

\section{CONCLUSIONS AND RECOMMENDATIONS}

\section{Conclusion}

From the results of statistical tests, the following conclusions are obtained:

1. Multiple Regression Testing is done to see the effect of the independent variable with the dependent variable. The results of the multiple regression equation obtained are:

$\mathrm{Y}=94,063-123,649 \mathrm{X} 1-57,628 \mathrm{X} 2+0.031 \mathrm{X} 3$ $+8.724 \mathrm{X} 4+\mathrm{E}$

The regression equation shows a negative relationship between KM and NP and KI against NP. A negative relationship means that the movement of $\mathrm{KM}$ and $\mathrm{KI}$ is not going in the same direction, when $\mathrm{KM}$ and $\mathrm{KI}$ increase, resulting in a decrease in NP and vice versa. There is a positive relationship between CSR on NP and IOS on NP. A positive relationship means the movement of CSR and IOS is not going in the same direction, when CSR and IOS have increased resulting in a decrease in NP and vice versa.

2. The coefficient of determination test results obtained by the value of $\mathrm{R}$ Square $=0.385$. This shows that $38.5 \mathrm{NP}$ variables are influenced by independent variables namely KM, IC, CSR and IOS. While the rest is explained by other factors.

\section{Suggestion}

Some suggestions that can be put forward in the results of this study are due to imperfections of research conducted by the author, the authors provide suggestions that are expected to gain knowledge from this research, as follows:

1. Need further research to be able to find out more things to influence NP in addition to KI, KM, CSR and IOS.

2. Research time should be made long, so that it can provide a better picture. Because the results are likely to be different when using different periods.

\section{REFERENCES}

1. Anggraini, Dewi. 2018. The Indonesia Sustainability Reporting Awards (ISRA) Announcement Influence On Abnormal Return and Stock Trade Volume (Empirical Study on ISRA Award-Winning Companies in 2009- 2016 Period). Archives of Business Research, 6(8), 6172.
2. Astriani, E.F. 2014. Pengaruh kepemilikan Manajerial, Leverage, Profitabilitas, Ukuran Perusahaan dan Investement Opportunity Set terhadap Nilai Perusahaan. Jurnal.

3. Frank Li Tao Li Dylan Minor. 2016. CEO power, corporate social responsibility, and firm value: a test of agency theory. International Journal of Managerial Finance, Vol. 12 Iss 5 pp.

4. Fosu, S., A. Danso., W. Ahmad., dan W. Coffie. 2016. Information asymmetry, leverage and firm value: Do crisis and growth matter?. International Review of Financial Analysis.

5. Ghozali, imam. 2013. Analisis Multivariate SPSS. Badan Penerbit Universitas Diponegoro. Semarang.

6. Halim, S. 2009. Dasar-dasar Manajemen Keuangan. Edisi Keenam. UPP STIM YKPN.Yogyakarta.

7. Harjoto, M. dan I. Laksamana. 2016. The Impact of Corporate Social Responsibility on Risk Taking and Firm Value. J Bus Ethics DOI 10.1007/s10551-016-3202-y.

8. Hidayah, N. 2015. Pengaruh Investment Opportunity Set (IOS) dan Kepemilikan Manajerial terhadap Nilai Perusahaan pada Perusahaan Property and Real Estate di Bursa Efek Indonesia. Jurnal Akuntansi/Volume XIX, No. 03.

9. Kasmir. 2013. Pengantar Manajemen Keuangan. Kencana. Jakarta.

10. Khafa, L. 2015. Pengaruh CSR, Ukuran Perusahaan, Leverage dan Keputusan Investasi pada Kinerja Keuangan Perusahaan dan Nilai Perusahaan. Skripsi. Universitas Diponegoro.

11. Kusumadilaga, R. 2010. Pengaruh Corporate Social Responsibility terhadap Nilai Perusahaan dengan Profitabilitas sebagai Variabel Moderating. Skripsi. Universitas Diponegoro.

12. Lisdawati, Hendri. 2017. Pengaruh Kinerja Lingkungan, Corporate Social Responsibility (CSR) dan Kinerja Keuangan Terhadap Nilai Perusahaan. Skripsi, Universitas Mercu Buana.

13. Octavia, L. 2013. Analisis Pengaruh Kebijakan Utang, Dividen, Profitabilitas dan Ukuran perusahaan terhadap Nilai Perusahaan Manufaktur di BEI periode 2008-2012. Skripsi. Universitas Diponegoro.

14. Osazuwa, N. P., dan A. Che-Ahmad. 2016. The moderating effect of profitability and leverage on the relationship between eco-efficiency and firm value in publicly traded Malaysian firms. Social Responsibility Journal, Vol. 12 Issue: 2.

15. Putri, G. A. P. 2013. Analisis Pengaruh Kepemilikan Institusional, Free Cash Flow, Investment Opportunity Set terhadap Nilai Perusahaan dengan Kebijakan Hutang sebagai Variabel Intervening. Skripsi. Universitas Diponegoro.

16. Putri, K. A., M. Sudarma., dan B. Purnomosidhi. 2016. Pengaruh Corporate Social Responsibility terhadap Nilai Perusahaan dengan Ukuran Perusahaan dan Jumlah Dewan Komisaris sebagai Variabel Pemoderasi. Jurnal Aplikasi Manajemen (JAM) Vol 14 No 2. 
17. Rahardjo, B. T., dan R. Murdani. 2016. Pengaruh Kinerja Keuangan dan Pengungkapan Corporate Social Responsibility terhadap Nilai Perusahaan. Jurnal akuntansi bisnis Vol. 3 No. 1 .

18. Rakasiwi, F. W., A. Pranaditya., dan R. Andini. 2017. Pengaruh EPS, Ukuran Perusahaan, Profitabilitas, Leverage, Sales Growth dan Kebijakan Dividen terhadap Nilai Perusahaan. Jurnal.

19. Sari, M. R. P. A., dan N. Handayani. 2016. Pengaruh Profitabilitas, Ukuran Perusahaan dan Laverage terhadap Nilai Perusahaan Transportasi. Jurnal Ilmu dan Riset Akuntansi : Volume 5, Nomor 9.

20. Sari, R.A.I., dan M.P. Priyadi. 2016. Pengaruh Leverage, Profitabilitas, Size dan Growth Opportunity terhadap Nilai Perusahaan. Jurnal Ilmu dan Riset Manajemen: Volume 5, Nomor 10.

21. Syardiana, G., A. Rodoni., dan Z. E. Putri. 2015. Pengaruh Investment Opportunity set, Struktur Modal, Pertumbuhan Perusahaan, dan Return on Asset terhadap Nilai Perusahaan. Jurnal Akuntansi. Vol. VIII No. 1.

22. Tanjung, P. R. S., Wahyudi, S. M., \& Chairunesia, W. (2019). Effect of Corporate Social Responsibility Disclosure And Good Corporate Governance Implementation On Response Coefficient Earnings (Asean Country Cross Study 2016-2018). Archives of Business Research, 7(7), 370-383.

$U R L$ : http://dx.doi.org/10.14738/abr.77.6822. 374

23. Zarlia, J., dan H. Salim. 2014. Analisis Pengaruh Corporate Social Responsibility dan Profitabilitas terhadap Nilai Perusahaan. Jurnal manajemen Vol. 11 No.2.

24. www.idx.co.id

25. www.sahamok.com 